\title{
Accumulation of cadmium and zinc in the marine sponge Suberites domuncula and its potential consequences on single-strand breaks and on expression of heat-shock protein: a natural field study
}

\author{
Werner E. G. Müller ${ }^{1, *}$, Renato Batel ${ }^{2}$, Markus Lacorn ${ }^{3}$, Hans Steinhart ${ }^{3}$, \\ Thomas Simat ${ }^{3}$, Stephanie Lauenroth ${ }^{1}$, Hamdy Hassanein ${ }^{1}$, Heinz C. Schröder ${ }^{1}$ \\ ${ }^{1}$ Institut für Physiologische Chemie, Abteilung Angewandte Molekularbiologie, Universität, Duesbergweg 6, \\ D-55099 Mainz, Germany \\ ${ }^{2}$ Center for Marine Research, 'Rudjer Boskovic' Institute, HR-52210 Rovinj, Croatia \\ ${ }^{3}$ Institut für Biochemie und Lebensmittelchemie, Universität, Grindelallee 117, D-20146 Hamburg, Germany
}

\begin{abstract}
The marine sponge Suberites domuncula (Porifera; Demospongiae) was used in a natural field study (in the vicinity of Rovinj. Croatia) as a bioindicator to assess the genotoxic risk of cadmium exposure for sponges as a model for invertebrates, and as an early stress marker of expression of heatshock protein $70\left(\mathrm{M}_{\mathrm{r}} 73 \mathrm{kDa}\right.$; termed HSP73). Significant differences in 'natural' cadmium levels of $S$. domuncula were found among sponges collected from differently polluted sites; in contrast zinc levels were relatively similar. Sponges living at polluted sites contained 15 to 24 times more cadmium than sponges at unpolluted reference sites. The capacity of $S$. domuncula to accumulate cadmium after an additional exposure to $5 \mathrm{mg} \mathrm{l}^{-1}$ of cadmium for $5 \mathrm{~d}$, was markedly higher (increase in cadmium content of 42 to $49 \mathrm{mg} \mathrm{Cd} \mathrm{kg}^{-1}$ ) for sponges collected from polluted sites compared to those from uncontaminated or less contaminated sites (increase of 8 to $29 \mathrm{mg} \mathrm{Cd} \mathrm{kg}^{-1}$ ); a strong increase in cadmium level was accompanied by a reduction in zinc level in the sponges from polluted sites. In this study we have used the rapid, sensitive and cheap Fast Micromethod ${ }^{\circledast}$ to determine the number of DNA single-strand breaks in $S$. domuncula collected from differently polluted sites and some of those sponges additionally exposed to cadmium. The strand scission factor (SSF) was found to depend on the pollution load; it further increased by 1.7 - to 8.6 -fold after additional exposure to cadmium (5 $\left.\mathrm{mg} \mathrm{l}^{-1}\right)$. Similarly, the levels of HSP73 were found to be highest in $S$. domuncula living at polluted sites. Additional exposure of the sponges to cadmium strongly increased HSP73 level. This increase in HSP73 level was higher in sponges from polluted sites compared to those collected from uncontaminated or less contaminated control sites. From these data we conclude that the sponge $S$. domuncula is a useful bioindicator regarding the cadmium load of the aquatic environment.
\end{abstract}

KEY WORDS: Cadmium Zinc D DNA damage - Heat-shock protein - Field study - Marine sponge Suberites domuncula

\section{INTRODUCTION}

Heavy metals, such as cadmium (Cd) and zinc (Zn), are natural constituents of seawater; their concentrations range from 0.01 (Sargasso Sea) to $0.1 \mathrm{ng} \mathrm{ml}^{-1}$ (North Pacific) for cadmium and from 0.01 (Sargasso

•E-mail:wmueller@goofy.zdv.uni-mainz.de
Sea) to $0.2 \mathrm{ng} \mathrm{m}^{-1}$ (Arctic) for zinc. But they also have to be considered as conservative pollutants (summarized in Clark 1997). Cadmium is associated with zinc in different minerals and is a byproduct during the purification of zinc (Berndt 1996). In addition, cadmium is frequently used as a component for plastics, solder and in batteries. Less than $10 \%$ of the cadmium commercially used is recycled (Clark 1997). 
Both cadmium and zinc are persistent metal ions which are not prone to bacterial degradation or detoxification. While zinc is an essential ion in many enzymes, e.g. proteases (Ogasawara et al. 1997), cadmium is not essential for any organism. Cadmium has been reported to cause a series of toxic effects, such as strong production of reactive oxygen species (Hassoun \& Stohs 1996), depletion of glutathione (Shimizu et al. 1997), inhibition of enzymes involved in DNA synthesis and repair (Yang et al. 1996), and DNA single-strand breaks (Hassoun \& Stohs 1996). These effects measured at the cellular level can be considered to be the major cause for the toxicity and carcinogenicity.

The most frequently discussed protection systems against exposure to toxic heavy metals present in higher invertebrates and in vertebrates are (1) metalbinding proteins (e.g. metallothioneins) and (2) heatshock proteins (Bauman et al. 1993, Ganguly et al. 1996). The expression of metallothioneins has been found to be induced by several heavy metals, e.g. Cd, $\mathrm{Zn}$ and $\mathrm{Hg}$ (reviewed in Hamer 1986). The increased expression of heat-shock proteins, especially of HSP70, in response to cadmium was demonstrated first for the nematode Caenorhabditis elegans (Guven \& De Pomerai 1995) and for vertebrate cells (from rats) (Bauman et al. 1993).

As bioindicator we used the demosponge Suberites domuncula for the following reasons. It is a species belonging to the lowest metazoan phylum, the Porifera. In general, sponges have been shown to be monophyletic with all other metazoan phyla and are provided with all basic structures and mechanisms (also protection mechanisms against environmental stress) known from higher metazoan phyla (reviewed in Müller 1997a, b, Müller \& Müller 1998); hence an extrapolation from its stress reactions to those of higher metazoan animals appears to be feasible. Furthermore, sponges are sessile filter feeders (Simpson 1984), some of which filter $24000 \mathrm{l} \mathrm{kg}^{-1}$ of sponge every day (Vogel 1977); they are the most abundant multicellular animals found in the marine hard-substrate benthos, both with respect to the number of species and in biomass (Sarà \& Vacelet 1973); and they are able to accumulate pollutants from the filtered water (Verdenal et al. 1990). They have been previously used successfully as bioindicator organisms (reviewed in Koziol et al. 1998b, Müller \& Müller 1998) and have been found to accumulate heavy metals under aquarium conditions (Olesen \& Weeks 1994, Hansen et al. 1995) With respect to the species, the sponge $S$. domuncula was selected because it is a cosmopolitan species which is abundantly present in the North Sea and the Mediterranean Sea (Arndt 1935), filters $20 \mathrm{l}(100 \mathrm{~g})^{-1}$ $\mathrm{d}^{-1}$ (Arndt 1930) and occurs in its natural habitat on muddy sand bottom both in the open sea and in harbors (Riedl 1983).

Among the different HSPs we selected HSP70 (size approximately $70 \mathrm{kDa}$ ), because it is the HSP species which reacts most strongly to both physiological and environmental stress in vertebrates (Sanders 1990) and in invertebrates, such as the nematode Caenorhabditis elegans (Guven et al. 1994) and the sponge Geodia cydonium (Koziol et al. 1996).

The aim of the present study was to evaluate the response of the biomarkers HSP70 and DNA singlestrand breaks in the marine sponge Suberites domuncula to Cd exposure. Secondly, the base values of both biomarkers as well as the 'natural' $\mathrm{Cd}$ content in sponges from differently polluted locations were determined in a field study.

\section{MATERIALS AND METHODS}

Materials. PicoGreen dsDNA quantitation reagent was purchased from Molecular Probes (Leiden, The Netherlands); monoclonal antibody against heat shock protein 70 [anti-hsp70 antibody (bovine); H 5147] was obtained from Sigma Chemical Co. (St. Louis, MO, USA).

Sponges from the field. Specimens of Suberites domuncula Olivi (Demospongiae: Tetractinomorpha: Hadromerida: Suberitidae: Suberites) were collected near Rovinj (Croatia; Mediterranean Sea, Adriatic Sea) and were either immediately frozen in liquid nitrogen until analysis or immediately exposed further to cadmium. They were taken at 5 different sites (Fig. 1), which are in the close vicinity of fixed sampling sites used in earlier environmental studies (Ugarkovic et al. 1990, Bihari \& Batel 1994) characterized by a distinct gradient of pollution. Site S-1 is a small bay at Rovinj (influence of a fish cannery); S-2 is at the rim of the harbour area of Rovinj (direct influence of the urban runoff and a tobacco factory) $\mathrm{S}-3$ is near the island of $\mathrm{S}$. Giovanni in Pelago (uncontaminated); $\mathrm{S}-4$ is the entrance to the Limski Kanal, close to the tourist camps of Blesicka in the north and Valalta in the south (tourist waste) and S-5 is $2 \mathrm{~km}$ from the end of the Limski Kanal (uncontaminated and only occasionally under the influence of a fish farm).

Focusing on genotoxic xenobiotics the following gradient has been demonstrated previously: S-2 $>$ S-1 $>\mathrm{S}-3>\mathrm{S}-4>\mathrm{S}-5$ [based on measurements of benzo(a)pyrene monooxygenase (BaPMO) activity in the livers of the fish Blennius pavo (Kurelec et al. 1977), frequency of chromosomal aberrations in the mussel Mytilus galloprovincialis (Al-Sabti \& Kurelec 1985) and induction of BaPMO in the livers of juvenile carp after i.p. injection of hexane-seawater extracts ('MFO induct test'; Kurelec et al. 1982)l 


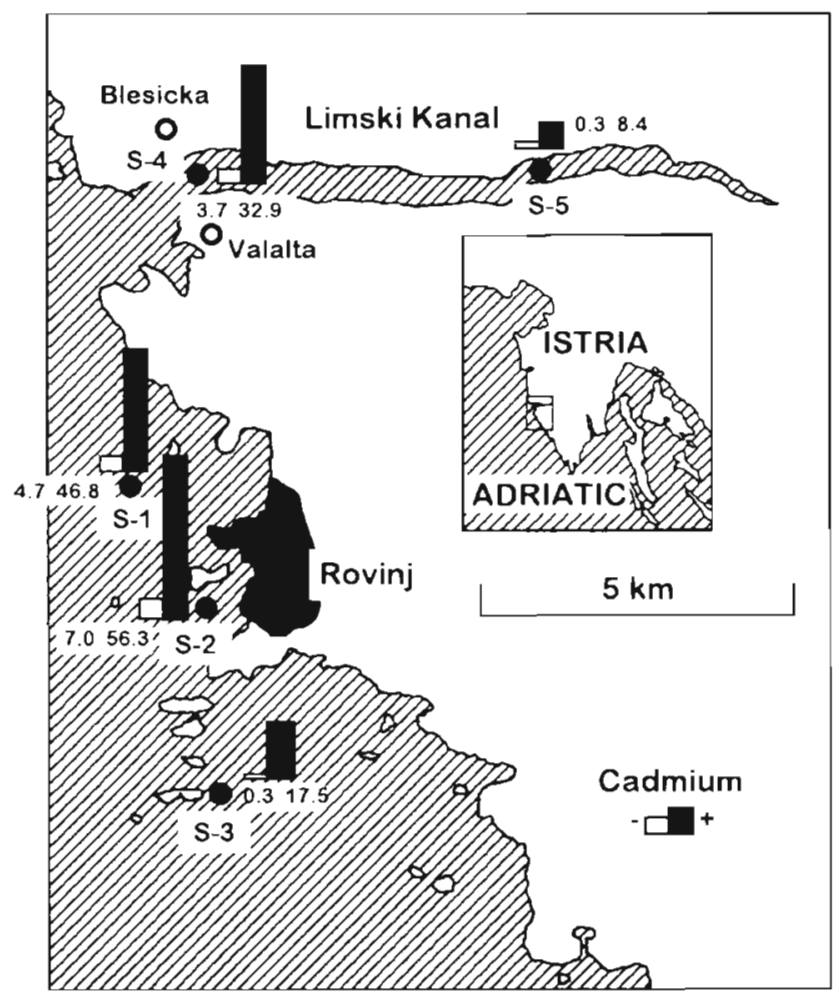

Fig. 1. Suberitis domuncula. Sampling sites for sponges in the Rovinj (Croatia) area (Northern Adriatic, Mediterranean Sea). Sites: S-1, Rovinj (fish cannery), S-2, Rovinj (harbour area); S-3, S. Giovanni in Pelago: S-4, entrance to the Limski Kanal (with the tourist camps Blesicka and Valalta); and S-5, end of the Limski Kanal. Bars (and the number below) mark the level of cadmium (mean values in $\mathrm{mg} \mathrm{kg}^{-1}$ wet weight) in tissue (1) from unexposed (in situ) sponges (open bars) and (2) from sponges taken from those sites and subsequently exposed to cadmium ( $5 \mathrm{mg} \mathrm{l}^{-1}$ for $5 \mathrm{~d}$ ) (closed bars). Further details are given under 'Materials and methods' and in Table 1

The sponges were collected during the period from August 14 to September 20,1997, by SCUBA diving at a depth of 10 to $25 \mathrm{~m}$ from the locations described above.

Exposure of Suberites domuncula to cadmium. Sponges from the indicated sites were taken and exposed to $5 \mathrm{mg} \mathrm{l}^{-1}$ of cadmium (corresponding to $8.16 \mathrm{mg} \mathrm{l}^{-1}$ of $\mathrm{CdCl}_{2}$ ) in seawater for $5 \mathrm{~d}$ in $20 \mathrm{l}$ aquaria at $17^{\circ} \mathrm{C}$ under continuous aeration; 1 specimen of approximately $40 \mathrm{~g}$ was kept in a surrounding volume of $>5 \mathrm{l}$. The water was changed once at Day 2. After exposure, the sponges were immediately frozen in liquid nitrogen and stored at $-80^{\circ} \mathrm{C}$.

Determination of metal contents. Sponge samples of approximately $200 \mathrm{mg}$ were digested with $2 \mathrm{ml}$ of concentrated $\mathrm{HNO}_{3}$ for $4 \mathrm{~h}$ at $150^{\circ} \mathrm{C}$ in PTFE pressure vessels according to the official German method (BgVV 1989a) and subsequently diluted with double distilled water. All solutions were analyzed by graphite furnace atomic absorption spectrophotometry with deuterium background correction (Pye Unicam 9200, Philips, Kassel, Germany) for cadmium (BgVV 1989b) Zinc was determined by flame atomic absorption spec trophotometry (Pye Unicam 9100, Philips) according to the described procedure (BgVV 1989c). All metal concentrations are expressed on a wet weight basis.

Accuracy and precision of the cadmium determination were tested by analyzing a certified reference material (CEC, Community bureau of reference, CRM No. 185, bovine liver). The mean was within the certified 0.95 confidence interval for cadmium and the coefficient of variation was $5 \%(n=10)$. Detection limits in the digested sample were $0.005 \mu^{-1} \mathrm{~g}^{-1}$ for cadmium and $2.5 \mu \mathrm{g} \mathrm{g}^{-1}$ for zinc. These results confirm the reliability of our analytical method.

Assay for alkaline labile sites in DNA. DNA damage analysis was carried out using a novel fluorometric technique that measures the rate of unwinding of cellular DNA after exposure to alkaline conditions; the sensitive and cheap Fast Micromethod ${ }^{\circledR}$ (Müller et al. 1997). In brief, the sponge tissue was homogenized in a mortar with a pestle under liquid nitrogen in $1 \mathrm{ml}$ of a $10 \mathrm{mM}$ Tris- $\mathrm{HCl}$ buffer $(\mathrm{pH} 7.4)$. The homogenate was applied to a black microplate, then lysing solution (9 $\mathrm{M}$ urea, pH 10.0) containing PicoGreen solution was added. Lysis of tissue was allowed to occur on ice in the dark. DNA denaturation (unwinding) at $\mathrm{pH} 12.4$ was allowed to take place. Measurements were performed at $480 \mathrm{~nm}$ excitation and $520 \mathrm{~nm}$ emission using a Fluoroskan II fluorescence ELISA plate reader (Labsystems, Helsinki, Finland). Each sample as well as the blank was measured in 6 replicates.

For calculation, the medium blank value was subtracted from all values. The zero time value for human lymphocytes, used as reference cells, was set at $100 \%$ dsDNA; all other values were calculated according to this statement. Effects are expressed as strand scission. factors (SSF), calculated after 20 min of denaturation, as follows: $\mathrm{SSF}=\log (\%$ dsDNA in sample $/ \%$ dsDNA in control). Negative values for SSF are indicative of increased frequencies of strand breaks.

Detection of heat-shock protein by Western blotting. Total tissue extracts were obtained as follows. Frozen sponge tissue was homogenized under liquid nitrogen in phosphate-buffered saline, supplemented with $500 \mathrm{mM} \mathrm{NaCl}$ and $5 \mathrm{mM}$ phenylmethylsulfonyl fluoride (PMSF). After centrifugation $\left(10000 \times g, 4^{\circ} \mathrm{C}\right.$, $30 \mathrm{~min}$ ) the supernatant ( $40 \mu \mathrm{g}$ of protein per slot) was subjected to electrophoresis in $10 \%$ polyacrylamide gels containing $0.1 \%$ sodium dodecyl sulfate as described by Laemmli (1970).

For Western blotting experiments the proteins were electro-transferred to PVDF-Immobilon P membranes (Millipore, Bedford, MA, USA) at $0.8 \mathrm{~mA} \mathrm{~cm}^{-2}$ for $1 \mathrm{~h}$ 
using a semi-dry blotting apparatus (Multiphor II; Pharmacia LKB) in blotting buffer (25 mM Tris, $192 \mathrm{mM}$ glycine, 20\% methanol; $\mathrm{pH} 8.3$ ). After blocking in Tris-buffered saline containing $5 \%$ milk powder protein (Nestle, Frankfurt, Germany) at $4{ }^{\circ} \mathrm{C}$ overnight, the membranes were incubated with monoclonal antiHSP70 antibodies (1:5000 dilution) in Tris-buffered saline containing $0.1 \%$ milk powder protein and $0.05 \%$ Tween 20 for $1.5 \mathrm{~h}$ at room temperature, followed by alkaline phosphatase-conjugated anti-mouse IgG for $1 \mathrm{~h}$ at room temperature. The immunoblots were stained using 5-bromo-4-chloro-3-indolyl phosphate/nitroblue tetrazolium.

Alternatively, an enhanced chemiluminescence method was employed using peroxidase-conjugated anti-mouse IgG and [disodium 3-(4-methoxyspiro1,2-dioxetane-3,2'-(5'-chloro)tricyclo[3.3.1.1]decan-4-yl) phenyl phosphatel (CSPD; Boehringer Mannheim), and blots were evaluated using a Model GS 525 Molecular Imager (Bio-Rad).

Statistical analysis. The results were analyzed by paired Student's t-test (Sachs 1984).

\section{RESULTS}

\section{Levels of cadmium and zinc in specimens collected from the field}

Determinations of cadmium levels in Suberites domuncula revealed significant differences between sponges collected from the different sites (Table $1_{\text {i }}$ see also Fig. 1). The lowest cadmium levels of $0.3 \mathrm{mg} \mathrm{kg}^{-1}$ fresh weight were found in sponges from the unpolluted or nearly unpolluted sites S-3 and S-5. The cadmium levels in sponges from the 'polluted' sites $\mathrm{S}-1$ and S-2 were 15 - to 24 -fold, and that of the less pol-

Table 1. Suberites domuncula. Levels of cadmium and zinc in sponges collected from differently polluted sites and additionally exposed to $5 \mathrm{mg} \mathrm{l}^{-1}$ of cadmium for $5 \mathrm{~d}$. Results are means $( \pm \mathrm{SD})$ of Cd determinations in $\mathrm{n}$ sponge individuals

\begin{tabular}{|ccrcc|}
\hline Site & $\begin{array}{c}\text { Additional } \\
\text { exposure }\end{array}$ & $\mathrm{n}$ & $\begin{array}{c}\text { Cadmium } \\
(\mathrm{mg} \mathrm{kg})\end{array}$ & $\begin{array}{c}\text { Zinc } \\
\left(\mathrm{mg} \mathrm{kg}^{-1}\right)\end{array}$ \\
\hline $\mathrm{S}-1$ & - & 6 & $4.69 \pm 0.67$ & $38.97 \pm 1.91$ \\
& + & 12 & $46.78 \pm 11.77$ & $22.87 \pm 7.48$ \\
$\mathrm{~S}-2$ & - & 6 & $7.00 \pm 0.99$ & $34.09 \pm 7.49$ \\
& + & 12 & $56.26 \pm 19.98$ & $16.21 \pm 3.17$ \\
$\mathrm{~S}-3$ & - & 12 & $0.29 \pm 0.01$ & $30.22 \pm 7.49$ \\
& + & 12 & $17.50 \pm 0.96$ & $27.22 \pm 3.22$ \\
$\mathrm{~S}-4$ & - & 12 & $3.72 \pm 0.12$ & $28.25 \pm 1.06$ \\
& + & 12 & $32.91 \pm 1.30$ & $24.87 \pm 4.85$ \\
$\mathrm{~S}-5$ & - & 12 & $0.32 \pm 0.01$ & $29.99 \pm 4.67$ \\
& + & 6 & $8.41 \pm 1.95$ & $38.32 \pm 2.65$ \\
& + & & & \\
\hline
\end{tabular}

luted site S-4 12-fold, higher compared to the levels at sites S-3 and S-5. In contrast to cadmium levels, the differences in the levels of zinc between sponges collected from contaminated and uncontaminated sites were less pronounced (Table 1).

\section{Exposure of Suberites domuncula to cadmium}

In order to determine the capacity of sponges living at sites of different pollution load to accumulate cadmium from the surrounding seawater, specimens of Suberites domuncula collected from these sites were additionally exposed to $5 \mathrm{mg}^{-1}$ of cadmium in aquaria

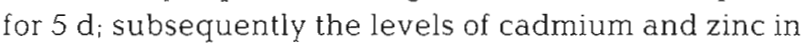
these sponges were determined. As shown in Table 1 and Fig. 1, all sponges responded to the additional metal stress with a strong accumulation of cadmium. However, the increases in cadmium levels in sponges collected from the uncontaminated or less contaminated sites S-3 (increase of $17.2 \mathrm{mg} \mathrm{kg}^{-1}$ ) and S-5 (8.1 $\mathrm{mg} \mathrm{kg} \mathrm{kg}^{-1}$ ) were markedly lower than in sponges that had been collected at the 'polluted' sites S-1 (increase of $42.1 \mathrm{mg} \mathrm{Cd} \mathrm{kg}^{-1}$ ) and S-2 (49.3 $\mathrm{mg} \mathrm{Cd} \mathrm{kg}^{-1}$ ); the increase in sponges from site $\mathrm{S}-4$ was intermediate,

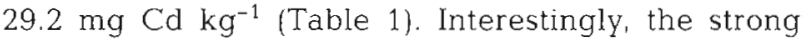
increase in cadmium level in sponges collected from polluted sites ( $\mathrm{S}-1$ and $\mathrm{S}-2$ ) was accompanied by a significant drop in zinc level $(\mathrm{p}<0.05)$; no significant change (sponges from unpolluted or less polluted sites S-3 and S-4) or even an increase in zinc level (animals from site S-5) was observed when sponges showing comparably low basal cadmium levels were addition-

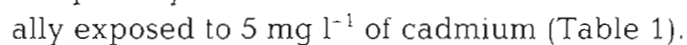

\section{Level of DNA single-strand breaks}

The occurrence of DNA single-strand breaks in sponges collected from differently polluted sites or in sponges after additional exposure to a single dose of cadmium ( $5 \mathrm{mg}^{-1}$ ) in vitro was determined using a newly developed, highly sensitive and Fast Micromethod $^{\otimes}$ (Müller et al. 1997). This method measures the unwinding of DNA under alkaline conditions using the fluorescence dye PicoGreen which specifically binds to double-stranded DNA. Fig. 2 shows that the number of alkaline labile sites, expressed as strand scission factor (SSF), increased in the following order: S-3, SSF $=0.022 ; \mathrm{S}-4, \mathrm{SSF}=0.057 ; \mathrm{S}-5, \mathrm{SSF}=0.098 ; \mathrm{S}-$ $1, \mathrm{SSF}=0.131 ;$ and $\mathrm{S}-2, \mathrm{SSF}=0.150$, roughly paralleling the gradient of pollution at these sites as determined in previous studies (Ugarkovic et al. 1990). The correlation coefficient between the amount of alkaline labile sites and cadmium concentrations in the tissue 


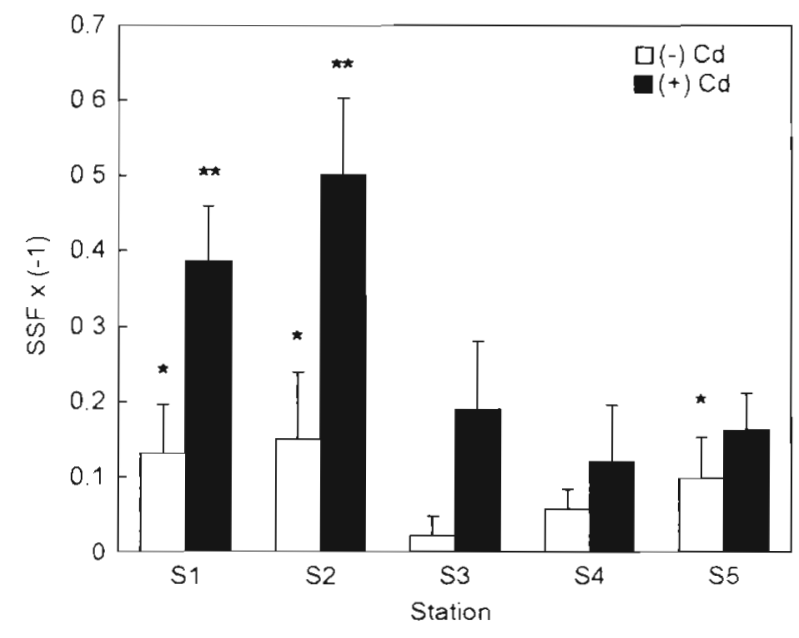

Fig. 2. Suberites domuncula. DNA damage in sponges living at differently polluted sites (see Fig. 1) (open bars) or collected from the mentioned field sites and then exposed to a single dose of cadmium (5 $\mathrm{mg} \mathrm{l}^{-1}$ ) for $5 \mathrm{~d}$ (closed bars). The number of alkaline labile sites was determined by the fast method using PicoGreen dsDNA quantitation reagent and is expressed as strand scission factor (SSF). The mean values ( $\pm \mathrm{SD}$ ) from 6 replicate determinations are shown. Significance: $p<0.01$

compared to site $\mathrm{S}-3 ; \cdots p<0.001$ compared to site S-3

samples was $r=0.732(p<0.01)$. The SSF values of sponges collected from polluted and unpolluted sites even increased by 1.7 - to 8.6 -fold following additional cadmium exposure and were 2- to 4 -fold higher in sponges from polluted sites $\mathrm{S}-1$ and $\mathrm{S}-2$, than in sponges from less polluted or unpolluted sites S-3, S-4 and S-5. The correlation coefficient was $\mathrm{r}=0.838(\mathrm{p}<$ $0.01)$.

\section{Level of expression of HSP70}

Western blotting experiments using a monoclonal antibody against bovine HSP70 revealed the presence of an immunoreactive protein band in Suberites domuncula, with a molecular mass of $73 \mathrm{kDa}$; this protein band becomes particularly prominent after an additional exposure of the sponge to cadmium (Fig. 3). The intensity of the HSP73 protein band varied considerably among sponge samples collected from differently polluted sites and then exposed to cadmium, being highest in sponges from the heavily polluted sites $\mathrm{S}-1$ and $\mathrm{S}-2$ and lower in those from the less polluted or unpolluted sites S-3, S-4 and S-5 (Fig. 3).

To quantify the levels of HSP73, immunoblots developed by the enhanced chemiluminescence method were exposed to a PhosphorImager screen and analyzed. The average level of HSP73 in sponges collected at site S-3 was set at 100\%. As shown in Fig. 4, the expression of HSP was highest in sponges living at the polluted sites S-1 and S-2 than in sponges living at the other, less polluted or unpolluted sites. The cadmium concentrations which had been determined in the tissue samples were correlated with the level of HSP73 expressed; the correlation coefficient was found to be $\mathrm{r}=0.819(\mathrm{p}<0.01)$. Additional exposure of the sponges collected from these sites to cadmium strongly increased expression of HSP73 (by 1.6- to 3.2-fold). The relative increase in cadmium-induced expression of HSP73 level was markedly higher in sponges from sites S-1 and S-2 (increase by 3.2-fold each) than in sponges from sites $S-3$ (1.7-fold), S-4 (1.6-fold) and S-5 (2.1-fold); the correlation coefficient between HSP73 level and cadmium concentration was $r=0.818(\mathrm{p}<$ $0.01)$.

\section{DISCUSSION}

To the best of our knowledge, there have been no natural field studies in which cadmium- and/or zinc levels were monitored using a bioindicator from lower metazoan phyla. In the mussel Mytilus galloprovincialis it was found that the amount of cadmium varied from 0.005 to $0.51 \mathrm{mg} \mathrm{kg} \mathrm{kg}^{-1}$ of tissue and reflected cadmium levels of the collection site (Mikulic 1994). Cadmium concentrations in nature might be a marker of exposure to cumulative effects of several pollutants; this pollutant burden predisposes organisms to greater stress if periodic increases in cadmium exposure occur (as is common in nature). For our field studies the

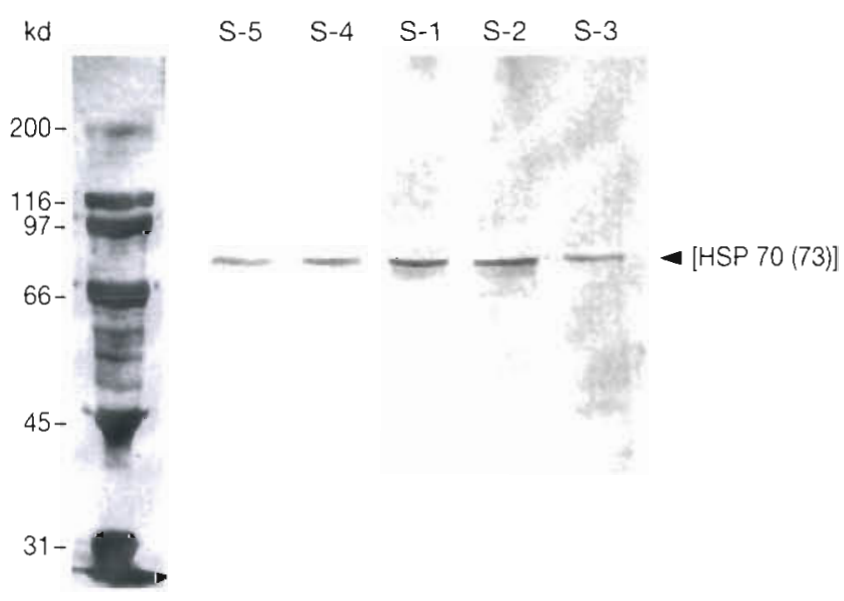

Fig. 3. Suberites domuncula. Immunodetection of heat shock protein in sponges collected from differently polluted sites and exposed to $5 \mathrm{mg} \mathrm{l}^{-1}$ of cadmium for $5 \mathrm{~d}$. Equalized amounts of protein $(40 \mu \mathrm{g})$ were applied to each slot. The position of migration of the heat shock protein band (HSP73) is indicated (arrowhead). The molecular masses of marker proteins, which were run in parallel (left lane), are given on the left 


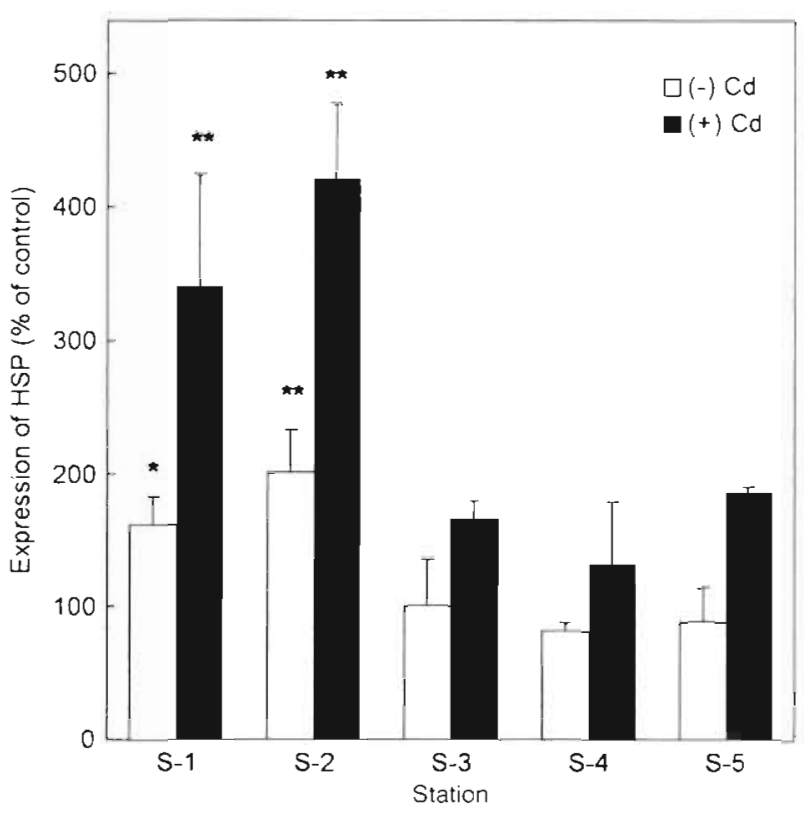

Fig. 4. Suberites domuncula. Levels of heat shock protein in sponges collected from differently polluted sites (open bars) or additionally exposed to $5 \mathrm{mg} \mathrm{l}^{-1}$ of cadmium for $5 \mathrm{~d}$ (closed bars). The results from Western blots exposed to a PhosphorImager screen were analyzed. The relative intensity of the HSP7 3 band at site S-3 was set at 100\%. Results are mean values ( \pm SD) of 3 sponge individuals. Significance: $p<0.01$ compared to site $S-3 ; \cdots p<0.001$ compared to site $S-3$

cosmopolitan sponge species Suberites domuncula was chosen because of the criteria summarized in the 'Introduction'. The area selected, around the town of Rovinj (12000 inhabitants; in the summer months there are in addition $>2$-fold more tourists), is well suited for natural field studies because it is located on the coast of the shallow northern part of the Adriatic Sea, it receives considerable freshwater discharge, mainly from the Po River (Italy) (Cavazzoni-Galaverni 1972), and it is exposed to 40 million inhabitant equivalents (expressed in biological oxygen demand for $5 \mathrm{~d}$ ) (Anonymous 1977). In addition, $7 \mathrm{~km}$ north of Rovinj a karstic underground mouth of a river opens to the $12 \mathrm{~km}$ long and $30 \mathrm{~m}$ deep 'Limski Kanal' which is a nonpolluted, protected, control site (Bihari \& Batel 1994).

We selected sites of different pollution around the area of Rovinj; these sites are marked in Fig. 1 (Ugarkovic et al. 1990, Bihari \& Batel 1994). Sites S-3 and S-5 are the reference sites of low environmental stress, while S-1 and S-2, the industry/urban sewage sites (the latter load will be reduced soon due to a functional sewer system to be introduced at the end of 1997), are known to be most exposed to genotoxic xenobiotics at the area selected. The state of induction of benzo(a)pyrene monooxygenase (BaPMO) activity in livers of the fish species Blennius pavo ranges from 1.6 (refer-

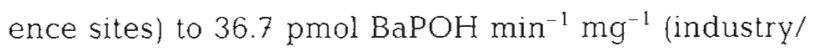
urban sewage sites) (Kurelec et al. 1977), frequency of chromosomal aberrations in Mytilus galloprovincialis from 2.9 (reference sites) to $9.6 \%$ (industry/urban sewage sites) (Al-Sabti \& Kurelec 1985); mixed functional oxygenase (MFO) induction in the livers of carp Cyprinus carpio using hexane extracts from reference sites, 2.1 to $46.2 \mathrm{pmol} \mathrm{BaPOH} \mathrm{min}^{-1} \mathrm{mg}^{-1}$ (industry/ urban sewage sites) (Kurelec et al. 1982); mutagenicity/carcinogenicity testing (Ames test) revealed only for the industry/urban sewage sites $60 \%$ revertants of Salmonella typhimurium (Kurelec et al. 1979).

It was determined that the amount of cadmium measured in the bioindicator sponge Suberites domuncula in situ ranged from $0.3 \mathrm{mg} \mathrm{kg}{ }^{-1}$ at the reference sites S-3 (outside of the industry/urban sites) and S-5 (end of the Limski Kanal) to a nearly 20 -fold higher concentration at the harbour (S-2) and the fish cannery sites (S-1). From these data 2 conclusions might be drawn; firstly, sponges are able to accumulate large amounts of heavy metals, even though the surrounding aqueous milieu has a cadmium load of $0.4 \mu \mathrm{g} \mathrm{l}^{-1}$ at S-1 and S-2 (Mikulic 1994) and does not change considerably between the different sites. According to the published data from this area, the cadmium concentration ranges between 0.1 (Pula area; south of Rovinj, Istria) and $0.5 \mathrm{\mu g} \mathrm{l}^{-1}$ (Pula-Siporex site) (Mikulic 1994). Secondly, sponges must be provided both with effective accumulation system(s) for heavy metals and efficient protection system(s) against the toxic effects displayed by cadmium.

In parallel to cadmium, the zinc concentration in specimens from the different sites was determined as well. It was found that, in contrast to cadmium, the amount of zinc did not vary considerably: a range from $28.3 \mathrm{mg} \mathrm{kg}^{-1}$ at site S-4 to $39.0 \mathrm{mg} \mathrm{kg}^{-1}$ at site $\mathrm{S}-1$ was determined. This finding is surprising in view of the fact that the concentration of zinc in the Northern Adriatic Sea varies strongly, from 15 to $3000 \mu \mathrm{g} \mathrm{l}^{-1}$ (Mikulic 1994). The experimental data summarized in the present study are in accordance with the data of Hansen et al. (1995), who reported that the sponge Halichondria panicea did not change the accumulation rate for zinc if incubated with concentrations of this metal between 1 and $1000 \mu \mathrm{g} \mathrm{l}^{-1}$. The concentration in the body was found to be approximately $100 \mu \mathrm{g} \mathrm{g}^{-1}$ dry weight (corresponding to $10 \mathrm{mg} \mathrm{kg}^{-1}$ fresh weight). This result implies that the zinc level is, in contrast to that of cadmium, strongly regulated in sponges.

In earlier studies it was shown that the sponge Halichondria panicea (Olesen \& Weeks 1994, Hansen et al. 1995 ) is able to accumulate cadmium in a concentration-dependent manner under laboratory conditions. The experiments revealed that this species accumulated $100 \mu \mathrm{g}$ of cadmium $\mathrm{g}^{-1}$ dry weight (correspond- 
ing to approximately $10 \mathrm{mg} \mathrm{kg}^{-1}$ wet weight) during a $14 \mathrm{~d}$ exposure to $1 \mathrm{mg}^{-1}$ of cadmium (Hansen et al. 1995). Using the same species Olesen \& Weeks (1994) determined a concentration factor of 42000 between the concentration of cadmium in the body and in the ambient water. In the present field study a concentration factor of 17500 was determined for Suberites domuncula, if the cadmium value in sponges at site $\mathrm{S}-2$ (7.00 $\mathrm{mg} \mathrm{kg}^{-1}$; this study) and an ambient cadmium concentration in the seawater (mean value $0.4 \mu \mathrm{gl}^{-1}$; Mikulic 1994) are used for this calculation. These data show that sponges in general and the species $S$. domuncula in particular are suitable monitoring organisms for the detection of a chronic exposure to relatively small cadmium concentrations.

In order to assess the potency of Suberites domuncula to adapt to rapid changes in surrounding cadmium concentrations, specimens were additionally exposed to cadmium in the aquarium. All examined sponges had the ability to accumulate additional cadmium to a great extent. It was found that if the specimens from the different locations were treated for $5 \mathrm{~d}$ in the presence of $5 \mathrm{mg} \mathrm{l}^{-1}$ of cadmium, the accumulation of the metal increased to values of 8.4 to $17.5 \mathrm{mg}$ $\mathrm{kg}^{-1}$ for specimens from the nonpolluted sites S-5 and $\mathrm{S}-3$, and 46.8 to $56.3 \mathrm{mg} \mathrm{kg}^{-1}$ for those from the polluted sites $\mathrm{S}-1$ and $\mathrm{S}-2$. These results imply that the sponges from the polluted sites contain more cadmium-binding moieties than those from the reference sites. Novel is the finding that the increased capacity of the sponges living at polluted sites to accumulate cadmium under 'induced' stress conditions is paralleled with a 2 -fold lower content of zinc. This remarkable finding suggests that the protection system of these sponges against cadmium is more potent and is used under extreme situations at the expense of the capacity to trap zinc. At present we contribute this finding to a differential capacity of the sponges to bind cadmium versus zinc. Future experiments must show whether sponges are also provided with metal-binding and heavy-metal-inducible proteins. From the high concentration factor determined here it is reasonable to assume that at least metallothionein-like polypeptides are present in sponges; furthermore it can be suggested that these proteins have different association constants to heavy metals, which are apparently lower (numerically) for zinc than for cadmium. It is known from vertebrates that zinc bound to metallothioneins can be displaced by cadmium (Chen et al. 1996).

Cadmium is a known carcinogenic metal in humans and in higher vertebrates, very likely due to induction of single strand DNA damage (see 'Introduction'; Shiraishi et al. 1995). The present study supports this finding and shows that the lowest metazoan phylum, the Porifera, is also prone to this metal ion. The strand scission factor (SSF), a measure of increased frequencies of DNA strand breaks, depended on the pollution load in Suberites domuncula collected from differently polluted sites and strongly increased following an additional cadmium exposure $\left(5 \mathrm{mg} \mathrm{l}^{-1}\right.$ of $\mathrm{Cd}$ for $5 \mathrm{~d}$ ). This increase in SSF was even higher in sponges from polluted sites compared to less polluted sites.

In an earlier report, applying the technique of alkaline elution, it was shown that the sponge Geodia cydonium responds to exposure to methyl mercury with a strong increase in DNA damage (Batel et al. 1993). In the present study we used the rapid, sensitive and cheap Fast Micromethod ${ }^{(*)}$ (Müller et al. 1997). This method, which is based on the analysis of DNA unwinding using a dsRNA-binding dye, allows determination of DNA strand breaks in 96-well plates within a time period of $3 \mathrm{~h}$ and requires only minimal amounts of material.

It is emphasized that until now no sign of tumor formation has been observed in sponges despite the fact that recent sequencing data provided evidence that these organisms are equipped with key molecules for tissue formation, e.g. integrin, galectin and fibronectin (Pfeifer et al. 1993, Müller 1997a, b, Pancer et al. 1997). The reason for this fact might be seen in the extreme regeneration potency of sponges due to their high levels of telomerase activity (Koziol et al. 1998a), with the presumed consequence of an elimination of those cells which have acquired an impaired function due to mutations. This property would also qualify sponges as a sensitive monitoring organism for genotoxic xenobiotics.

In earlier studies it was shown that both vertebrate cells, e.g. from humans (Polla et al. 1995), and invertebrate cells, e.g. from Caenorhabditis elegans (Guven \& De Pomerai 1995), react with a differential expression of HSP70 proteins in response to heat and to cadmium. Interesting is the finding that in $C$. elegans the expression of the constitutive HSP70 is very low under nonstressed conditions but increases strongly after incubation in the presence of heat and cadmium (Guven \& De Pomerai 1995); this finding suggests that more work is required to understand which heat-shock protein of the $M_{r}$ species 70000 responds to a given stressor (Guven \& De Pomerai 1995). In earlier experiments we demonstrated that sponges also react to heat (Koziol et al. 1996), different nonphysiological physical conditions (Koziol et al. 1996, 1997), and xenobiotics (Müller et al. 1995) with an increased expression of the gene(s) coding for HSP70. Therefore, we analyzed whether HSP70 is also a suitable biomarker for increased cadmium load of Suberites domuncula in the environment. The data documented here clearly show that the degree of expression of the HSP70 gene(s) in areas of higher load with xenobiotics, e.g. site S-1 and S-2 is much higher than in nonpolluted areas, as in S-3 or S-5. 
Acknowledgements. This work was supported by a grant from the Bundesministerium für Bildung und Forschung (Project 'STRESSTOX'). The authors thank Silke Gnädig and Britta Scheffler for their assistance in the maintenance and analysis of sponges.

\section{LITERATURE CITED}

Al-Sabti K, Kurelec B (1985) Induction of chromosomal aberrations in the mussel Mytilus galloprovincialis watch. Bull Environ Contam Toxicol 35:660-665

Anonymous (1977) Indagine sulla qualità della acque del fiume Po. CNR, Instituto di Ricerca sulle Acque, Roma, Quaderni (32)

Arndt W (1930) Schwämme (Porifera, Spongien). Tabulae Biologicae VI (Suppl II):41-120

Arndt W (1935) Porifera. In: Grimpe G (ed) Tierwelt der Nordund Ostsee. Akademische Verlagsgesellschaft, Leipzig, p IIIa1-IIIa139

Batel R, Bihari N, Rinkevich B, Dapper J, Schäcke $H$, Schröder HC, Müller WEG (1993) Modulation of organotin-induced apoptosis by the water pollutant methyl mercury in a human lymphoblastoid tumor cell line and a marine sponge. Mar Ecol Prog Ser 93:245-251

Bauman JW, Liu J, Klaassen CD (1993) Production of metallothionein and heat-shock proteins in response to metals. Fund Appl Toxicol 21:15-22

Berndt J (1996) Umweltbiochemie. Gustav Fischer-Verlag, Stuttgart

BgVV (Bundesamt für gesundheitlichen Verbraucherschutz und Veterinärmedizin) (1989a) L. 00.00.19/1: Bestimmung von Spurenelementen in Lebensmitteln, Teil 1. Druckaufschluß. In: Amtliche Sammlung von Untersuchungsverfahren nach § 35 LMBG, Beuth Verlag GmbH, Berlin

$\mathrm{BgVV}$ (Bundesamt für gesundheitlichen Verbraucherschutz und Veterinärmedizin) (1989b) L 00.00.19/3: Bestimmung von Spurenelementen in Lebensmitteln, Teil 3: Bestimmung von Blei, Cadmium, Chrom und Molybdän mit der Atomabsorptionsspektrometrie (AAS) im Graphitrohr. In: Amtliche Sammlung von Untersuchungsverfahren nach $\S 35$ LMBG, Beuth Verlag GmbH, Berlin

BgVV (Bundesamt für gesundheitlichen Verbraucherschutz und Veterinärmedizin) (1989c) L 00.00.19/2: Bestimmung von Spurenelementen in Lebensmitteln, Teil 2: Bestimmung von Eisen, Kupfer, Mangan und Zink mit der Atomabsorptionsspektrometrie (AAS) in der Flamme. In: Amtliche Sammlung von Untersuchungsverfahren nach $\S 35$ LMBG, Beuth Verlag GmbH, Berlin

Bihari N, Batel R (1994) Alkaline elution of mussel DNA as a tool for determination of environmental contamination by genotoxins. In: Muller WEG (ed) Use of aquatic invertebrates as tools for monitoring of environmental hazards. Gustav Fischer-Verlag, Stuttgart, p 35-48

Cavazzoni-Galaverni S (1972) Distribuzione costiera delle acque dolci continentali nel mare Adriatico (fino alla trasversale Tremiti-Curzola). Rapp Tec No. 44 CNR, Laboratorio per lo Studio della Dinamica delle Grandi Masse, Venezia, p 18

Chen P, Munoz A, Nettesheim D, Shaw CF, Petering DH (1996) Stoichiometry and cluster specificity of copper binding to metallothionein: homogeneous metal clusters Biochem. J 317:395-402

Clark RB (1997) Marine pollution. Clarendon Press, Oxford

Ganguly S, Taioli E, Baranski B, Cohen B, Toniolo P, Garte SJ (1996) Human metallothionein gene expression determined by quantitative reverse transcription-polymerase chain reaction as a biomarker of cadmium exposure. Cancer Epidemiol Biomarker Prev 5:297-301

Guven K, De Pomerai DI (1995) Differential expression of HSP70 proteins in response to heat and to cadmium in Caenorhabditis elegans. J Therm Biol 20:355-363

Guven K, Duce JA, De Pomerai DI (1994) Evaluation of stressinducible transgenic nematode strain for rapid aquatic toxicity testing. Aquat Toxicol 29:119-137

Hamer DH (1986) Metallothionein. Annu Rev Biochem 55: 913-951

Hansen IV, Weeks JW, Depledge MH (1995) Accumulation of copper, zinc, cadmium and chromium by the marine sponge Halichondria panicea Pallas and the implications for biomonitoring. Mar Pollut Bull 31:133-138

Hassoun EA, Stohs SJ (1996) Cadmium-induced production of superoxide anion and nitric oxide, DNA single strand breaks and lactate dehydrogenase leakage in J774A.1 cell cultures. Toxicology 112:219-226

Koziol C, Batel R, Arinc E, Schröder HC, Müller WEG (1997) Expression of the potential biomarker heat shock protein 70 and its regulator, the metazoan DnaJ homolog, by temperature stress in the sponge Geodia cydonium. Mar Ecol Prog Ser 154:261-268

Koziol C, Borojevic R, Steffen R, Müller WEG (1998a) Sponges (Porifera) model systems to study the shift from immortal to senescent somatic cells: the telomerase activity in somatic cells. Mech Ageing Develop 100:107-120

Koziol C, Scheffer U, Pancer Z, Krasko A, Müller WEG (1998b) Sponges as biomarkers of the aquatic environment: application of molecular probes. In: Watanabe $Y_{\text {, }}$ Fusetani N (eds) Sponge science. Springer-Verlag, Tokyo, p $121-132$

Koziol C, Wagner-Hülsmann C, Cetkovic H, Gamulin V Kruse M, Pancer Z, Schäcke H, Müller WEG (1996) Cloning of the heat-inducible biomarker, the cDNA encoding the $70 \mathrm{kDa}$ heat shock protein, from the marine sponge Geodia cydonium: response to natural stressors. Mar Ecol Prog Ser 136:153-161

Kurelec B, Britvic S, Rijavec M, Müller WEG, Zahn RK (1977) Benzo(a)pyrene monooxygenase induction in marine fish - molecular response to pollution. Mar Biol 44:211-216

Kurelec B, Matijasevic $Z$, Rijavec $M$, Alacevic $M$, Britvic $S$, Müller WEG, Zahn RK (1979) Induction of benzo(a)pyrene monooxygenase in fish and Salmonella test as tool for detecting mutagenic/carcinogenic xenobiotics in the aquatic environment. Bull Environ Contam Toxicol 21: $799-807$

Kurelec B, Protic M, Rijavec M, Britvic S, Müller WEG, Zahn RK (1982) Induction of benzo(a)pyrene monooxygenase in fish after i.p. application of water hexane extract - a prescreen tool for detection of xenobiotics. In: Richards NL, Jackson BL (eds) Carcinogenic polynuclear aromatic hydrocarbons in the marine environment. Environmental Research Laboratory, Gulf Breeze, FL, p 124-136

Laemmli UK (1970) Cleavage of structural proteins during the assembly of the head of bacteriophage T4. Nature 227: $680-685$

Mikulic $N$ (ed) (1994) Monitoring programme of the Eastern Adriatic Coastal Area (1983-1991). United Nations Environmental Programme, MAP Tech Rep Ser 86, p 275

Müller WEG (1997a) Molecular phylogeny of Eumetazoa: experimental evidence for monophyly of animals based on genes in sponges [Porifera]. Prog Molec Subcell Biol 19: $98-132$

Müller WEG (1997b) Origin of metazoan adhesion molecules and adhesion receptors as deduced from their cDNA analyses from the marine sponge Geodia cydonium: a 
review. Cell Tissue Res 289:383-395

Müller WEG, Batel R, Zahn RK, Bihari N, Schröder HC (1997) Mikro-Methode zur Schnellbestimmung von DNASchäden und deren Reparatur unter Verwendung des Fluoreszenzfarbstoffes Picogreen und Ihre Anwendung. Patent application 19724781.4 (12.06.1997)

Müller WEG, Koziol C, Kurelec B, Dapper J, Batel R, Rinkevich $B$ (1995) Combinatory effects of temperature stress and nonionic organic pollutants on stress protein (hsp70) gene expression in the fresh water sponge Ephydatia fluviatilis. Environ Toxicol Chem 14:1203-1208

Müller WEG, Müller I (1998) Sponge cells and tissue as biological monitors of aquatic pollution. In: Wells $P G_{\text {, }}$ Lee $K$, Blaise $C$ (eds) Microscale aquatic toxicology-advances, techniques and practice. CRC Lewis Publishers, Boca Raton, FL, p 97-112

Ogasawara W, Abe N, Hagio T, Okada H, Morikawa Y (1997) Purification and characterization of a dipepdidyl carboxypeptidase from Pseudomonas sp. W024. Biosci Biotechnol Biochem 61:858-863

Olesen TME, Weeks JM (1994) Accumulation of Cd by the marine sponge Halichondria panicea Pallas: effects upon filtration rate and its relevance for biomonitoring. Bull Environ Contam Toxicol 52:722-728

Pancer Z, Kruse M, Müller I, Müller WEG (1997) On the origin of adhesion receptors of metazoa: cloning of the integrin subunit cDNA from the sponge Geodia cydonium. Molec Biol Evol 14:391-398

Pfeifer K, Haasemann M, Gamulin V, Bretting H, Fahrenholz F, Muller WEG (1993) S-type lectins occur also in invertebrates: high conservation of the carbohydrate recognition domain in the lectin genes from the marine sponge Geodia cydonium. Glycobiol 3:179-184

Polla BS, Stubbe H, Kantengwa S, Maridonneau-Parini l, Jacquier-Sarlin MR (1995) Differential induction of stress proteins and functional effects of heat shock in human phagocytes. Inflammation 19:363-378

Editorial responsibility: Otto Kinne (Editor), Oldendorf/Luhe, Germany
Riedl R (1983) Fauna und Flora des Mittelmeers. Verlag Paul Parey, Hamburg

Sachs L (1984) Angewandte Statistik. Springer-Verlag, Berlin, p 242

Sanders BM (1990) Stress proteins: potential as multitiered biomarkers. In: McCarthy JF, Shugart LR (eds) Biomarkers of environmental contamination. Lewis, Boca Raton, FL, p $165-191$

Sarà M, Vacelet J (1973) Ecologie des Démosponges. In: Grassé PP (ed) Traité de zoologie: Spongiaires. Tome III (1). Masson, Paris, p 462-576

Shimizu M, Hochadel JF, Waalkes MP (1997) Effects of glutathione depletion on cadmium-induced metallothionein synthesis, cytotoxicity, and proto-oncogene expression in cultured rat myoblasts. J Toxicol Environ Health 51: 609-621

Shirashi N, Hochadel JF, Coogan TP, Koropatnick J, Waalkes MP (1995) Sensitivity to cadmium-induced genotoxicity in rat testicular cells is associated with minimal expression of metallothionein gene. Toxicol Appl Pharmacol 130: $229-236$

Simpson TL (1984) The cell biology of sponges. SpringerVerlag, New York

Ugarkovic D, Kurelec B, Krca S, Batel R, Robitzki A, Müller WEG, Schröder HC (1990) Alterations in ras-gene expression and intracellular distribution of protein kinase $C$ in the sponge Geodia cydonium on response to marine pollution. Mar Biol 107:191-197

Verdenal B, Diana C, Arnoux A, Vacelet J (1990) Pollutant levels in Mediterranean commercial sponges. In: Rützler K (ed) New perspectives in sponge biology, Smithsonian Institution Press, Washington, DC, p 416-424

Vogel S (1977) Current-induced flow through living sponges in nature. Proc Natl Acad Sci USA 74:2069-2071

Yang SW, Becker FF, Chan JY (1996) Inhibition of human DNA ligase I activity by zinc and cadmium and the fidelity of ligation. Environ Mol Mutagen 28:19-25

Submitted: December 1, 1997; Accepted: March 12, 1998

Proofs received from author(s): May 22, 1998 